Received: 22 January 2019

Accepted: 30 May 2019

Published online: 13 June 2019

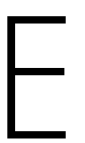

C N
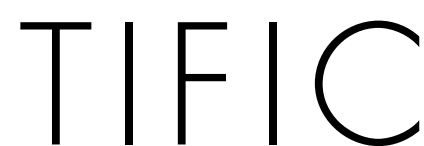

REP

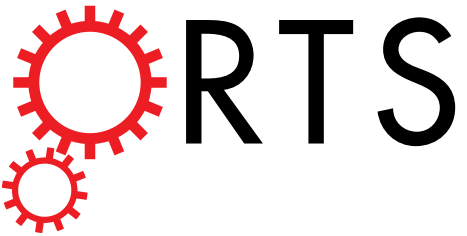

OPEN

\title{
The yeast scavenger decapping enzyme DcpS and its application for in vitro RNA recapping
}

Madalee G. Wulf, John Buswell, Siu-Hong Chan, Nan Dai, Katherine Marks, Evan R. Martin, George Tzertzinis, Joseph M. Whipple, Ivan R. Corrêa Jr. (1) \& Ira Schildkraut

Eukaryotic mRNAs are modified at their $5^{\prime}$ end early during transcription by the addition of $\mathrm{N7}$ methylguanosine $\left(\mathrm{m}^{7} \mathrm{G}\right)$, which forms the "cap" on the first $5^{\prime}$ nucleotide. Identification of the $5^{\prime}$ nucleotide on mRNA is necessary for determination of the Transcription Start Site (TSS). We explored the effect of various reaction conditions on the activity of the yeast scavenger mRNA decapping enzyme DcpS and examined decapping of 30 chemically distinct cap structures varying the state of methylation, sugar, phosphate linkage, and base composition on 25mer RNA oligonucleotides. Contrary to the generally accepted belief that DcpS enzymes only decap short oligonucleotides, we found that the yeast scavenger decapping enzyme decaps RNA transcripts as long as 1400 nucleotides. Further, we validated the application of $y$ DcpS for enriching capped RNA using a strategy of specifically tagging the $5^{\prime}$ end of capped RNA by first decapping and then recapping it with an affinity-tagged guanosine nucleotide.

The $5^{\prime}$ ends of eukaryotic messenger RNA (mRNA) carry a $5^{\prime}$ to $5^{\prime}$ triphosphate linked 7 -methyl-guanosine $\left(\mathrm{m}^{7} \mathrm{G}\right)$ cap. The capping occurs at an early stage of transcription and is involved in splicing, stabilizing and directing the transcript to the cytoplasm where it is translated. In higher eukaryotes, the canonical $\mathrm{m}^{7} \mathrm{G}$ cap can be further modified by $2^{\prime}-O$-methylation at nucleotide positions +1 (Cap 1) and +2 (Cap 2) of the RNA. Both capping and decapping of mRNA are critical components of gene expression. The enzymes responsible for the decapping have been described from two distinct protein families, the Nudix pyrophosphohydrolases ${ }^{1}$ and the HIT family of pyrophosphatases ${ }^{2,3}$. The distinguishing characteristic of catalysis by the two families of decapping enzyme is the resulting products of the reactions (Fig. 1). Nudix decapping enzymes perform metal dependent hydrolysis of the phosphodiester bond between the beta and alpha phosphates to leave a $5^{\prime}$-monophosphate RNA ( $p$ RNA) and a 7-methyl-guanosine diphosphate $\left(\mathrm{m}^{7} \mathrm{GDP}\right)$. A few exceptions have been reported where nudix decapping activities result in mixed diphosphate and monophosphate $5^{\prime}$ RNA ends ${ }^{1}$. On the other hand, HIT decapping enzymes, including the so-called scavenger decapping enzyme DcpS, hydrolyze the phosphodiester bond between the gamma and beta phosphates to leave a $5^{\prime}$-diphosphate-RNA ( $p p$ RNA) and a 7-methyl-guanosine monophosphate ${ }^{4,5}\left(\mathrm{~m}^{7} \mathrm{GMP}\right)$ and are independent of divalent metal ions ${ }^{6}$. An exception to the HIT family is the FHIT subfamily some members of which were found to leave mixed 7mGDP and 7mGMP 7,8 . Recently an additional type of decapping enzyme was described from trypanosomes. TbALPH1 an ApaH-like phosphatase removes $7 \mathrm{mGMP}$ from the cap structure to leave a diphosphate $5^{\prime} \mathrm{end}^{7,9}$.

DcpS proteins of the HIT family have been identified in fungi and animals. DcpS contains a conserved set of histidines, the histidine triad sequence, which is necessary for catalysis. These enzymes are reported to "scavenge" the $\mathrm{m}^{7} \mathrm{GMP}$ from the $5^{\prime}$ terminus of short mRNA fragments that are produced after extensive $3^{\prime}$ to $5^{\prime}$ exonuclease digestion by the exosome complex. Capped RNAs of a length of ten nucleotides and longer have been reported to be resistant to decapping with the human $\mathrm{DcpS}^{4,10}$. Both human and yeast DcpS have been shown to play a biological role in the $3^{\prime}$ to $5^{\prime}$ mRNA decay pathway ${ }^{4,11}$.

The yeast scavenger decapping enzyme is encoded by the Saccharomyces cerevisiae DCS1 gene and its protein product is referred to here as yDcpS. In this study we examine yDcpS activity with respect to cap structure specificity and RNA substrate length. The focus of our study is not to investigate the biological role of DcpS, but rather to study the enzyme in vitro in order to establish conditions in which it might be useful for manipulating RNA. We demonstrate that yDcpS under specified conditions can decap RNA of a length up to at least $1.4 \mathrm{~kb}$,

New England Biolabs, Inc., 240 County Road, Ipswich, MA, 01938, USA. Correspondence and requests for materials should be addressed to I.S. (email: schildkraut@neb.com) 


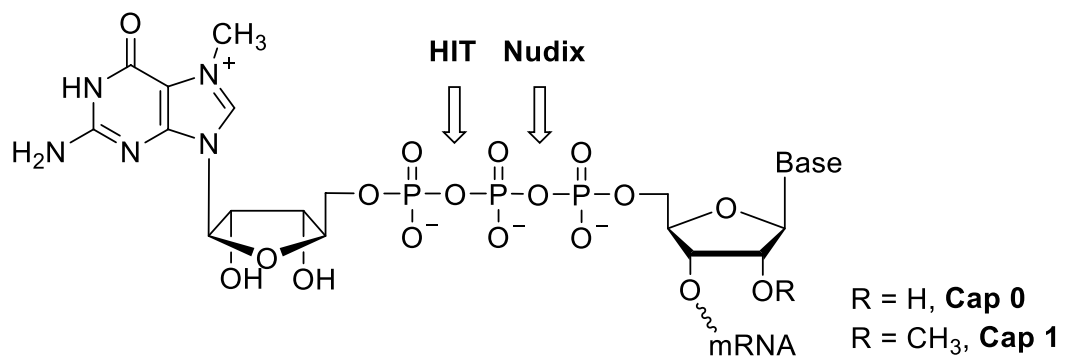

Figure 1. Cap structure and site of hydrolysis for the HIT and Nudix enzymes.

thus rendering the $5^{\prime}$ end of the RNA enzymatically "recappable". In addition, we have determined the in vitro specificity of yDcpS with respect to 30 different cap analog structures at the $5^{\prime}$ end of a $25 \mathrm{mer}$ RNA substrate. These analogs include Cap 0 and Cap 1 structures varying the nucleotide at position +1 of the RNA (A, $m^{6} \mathrm{~A}, \mathrm{C}$, $\mathrm{G}$, or $\mathrm{U})$, as well as the identity $\left(\mathrm{G}, \mathrm{dG}\right.$, araG, $\mathrm{I}, \mathrm{A}, \mathrm{C}$, $\mathrm{U}$, or nicotinamide) and methylation status $\left(\mathrm{m}^{7} \mathrm{G}, \mathrm{m}^{2,2,7} \mathrm{G}\right.$ and unmethylated $\mathrm{G}$ ) of the cap nucleotide, and the length of the internucleotidic phosphate bridge (di-, tri- or tetraphosphate). Our results indicate that DcpS can decap most guanosine caps; in contrast, it shows no activity towards adenosine, cytidine or uridine capped RNAs.

In a previous work, we developed a method termed Cappable-seq. ${ }^{12}$ to enrich primary prokaryotic RNA transcripts by capping their $5^{\prime}$ triphosphate with $3^{\prime}$-desthiobiotin-GTP (DTB-GTP). In an effort to extend this method to eukaryotic mRNA, we demonstrate here that yDcpS can decap the $5^{\prime}$ end of $\mathrm{m}^{7} \mathrm{G}$-capped RNA transcripts of a length from 90 to 1400 nucleotides without appreciable length bias. Further, the yDcpS-treated transcripts can be recapped with DTB-GTP and recovered after binding to, and eluting from, streptavidin beads.

\section{Results}

Liu et al. ${ }^{4}$ and Cohen et al. ${ }^{13}$ presented data indicating that human DcpS (hDcpS) does not decap RNAs longer than approximately ten nucleotides. Cohen et al. showed that the nematode DcpS was even more limited in its ability to decap oligonucleotides longer than 3 nucleotides ${ }^{13}$. This precept of acting solely on capped short oligonucleotides has been attributed to all homologous HIT enzymes ${ }^{14}$, despite Salehi et al..$^{15}$ identifying a HIT protein in Schizosaccharomyces pombe, Nhm1, which was determined to decap long mRNA. Nhm1 has about 70\% amino acid sequence similarity to the yeast and human DcpS enzymes. As these two disparate DcpS activities, one decapping only short $\mathrm{RNA}^{4,13}$ the other decapping $\mathrm{mRNA}^{15}$ are conflicting, we decided to characterize yDcpS with respect to its ability to decap RNA of different lengths. We used recombinant yDcpS expressed in E. coli and purified to homogeneity as described in Methods.

Pyrophosphorolysis of the $\mathrm{m}^{7} \mathrm{GpppA}$ dinucleotide. We first looked at catalysis of the dinucleotide cap analog $\mathrm{m}^{7} \mathrm{GpppA}$, as the characterization of DcpS typically involves pyrophosphorolysis of cap analogs which are dinucleotides of NpppN structure ${ }^{4,6,8,16,17}$. Cap analogs can be considered as a capped RNA of one nucleotide in length. Both Malys et al. ${ }^{18}$ and Liu et al. ${ }^{19}$ demonstrated the pyrophosphorolysis of $\mathrm{m}^{7} \mathrm{GpppG}$ dinucleotide with a rate constant of $0.012 / \mathrm{sec}$ for $\mathrm{yDcpS}$ and $0.09 / \mathrm{sec}$ for hDcpS, respectively. We compared the relative activity of $\mathrm{hDcpS}$ and $\mathrm{yDcpS}$ towards the $\mathrm{m}^{7} \mathrm{GpppA}$ dinucleotide. We determined the decapping rate at $50 \mu \mathrm{M} \mathrm{m} \mathrm{m}^{7} \mathrm{GpppA}$ dinucleotide by LC/MS analysis (Fig. 2a). The results indicate the two enzymes catalyze the pyrophosphorolysis of dinucleotide with similar rates: $y D c p S$ at $0.08 / \mathrm{sec}$ and $\mathrm{hDcpS}$ at $0.14 / \mathrm{sec}$. Although the rate constant seen here for yDcpS is about 7 times faster than that reported by Malys et al., their incubation temperature was lower $\left(30^{\circ} \mathrm{C}\right)$, the ionic strength was greater $(100 \mathrm{mM} \mathrm{KOAc})$ and the $\mathrm{pH}$ was higher $(\mathrm{pH} 7.0)$. Thus the catalysis of the dinucleotide observed with our preparation of $y \mathrm{DcpS}$ is consistent with published literature. The human DcpS was shown by Liu et al. ${ }^{19}$ to display negative cooperativity as indicated by a 10 -fold higher rate at lower dinucleotide concentration $(10 \mathrm{nM})$. The comparison of rates between human and yeast DcpS in our study was performed at much higher dinucleotide concentration $(50 \mu \mathrm{M})$ which was well beyond the dinucleotide concentration necessary to demonstrate a 10 fold reduced rate.

Yeast DcpS decaps a 25mer RNA. To determine whether yDcpS can decap an RNA longer than 15 nucleotides, a 25mer Cap 1 RNA synthesized and capped in vitro, was used as a substrate. As we have previously observed that addition of extraneous RNA acts as a competitive inhibitor for the reaction, we added E. coli RNA to the reaction shown in Fig. $2 \mathrm{~b}$ to more closely simulate a decapping reaction where only a subset of total eukaryotic RNA would be substrate for the DcpS. This mixture was incubated with yDcpS, and aliquots were sampled over time and analyzed by gel electrophoresis. As shown in Fig. 2b, with increasing incubation time of up to three hours, a larger fraction of the 25mer RNA is shifted to the position of the decapped species, demonstrating that $\mathrm{yDcpS}$ is capable of decapping a longer RNA than what was reported previously.

The effect of ionic strength and $\mathrm{pH}$ on decapping activity. In vitro decapping of DcpS was assessed at various ionic strength and $\mathrm{pH}$ conditions by using a synthetic 25 mer Cap 0 RNA $3^{\prime}$ modified with a 6-carboxyfluorescein ( $3^{\prime}$-FAM) label. Substrate and product of the decapping reaction were resolved and quantified by capillary electrophoresis (CE) (Fig. 2c). As shown in Table 1, the decapping reaction is significantly inhibited by increasing salt concentration, with $\mathrm{KCl}$ being a more potent inhibitor than $\mathrm{NaCl}$. The optimal buffering $\mathrm{pH}$ was in the 6-6.5 range. $\mathrm{yDcpS}$ exhibited very little decapping activity in the Vaccinia Capping Buffer at $\mathrm{pH}$ 
a
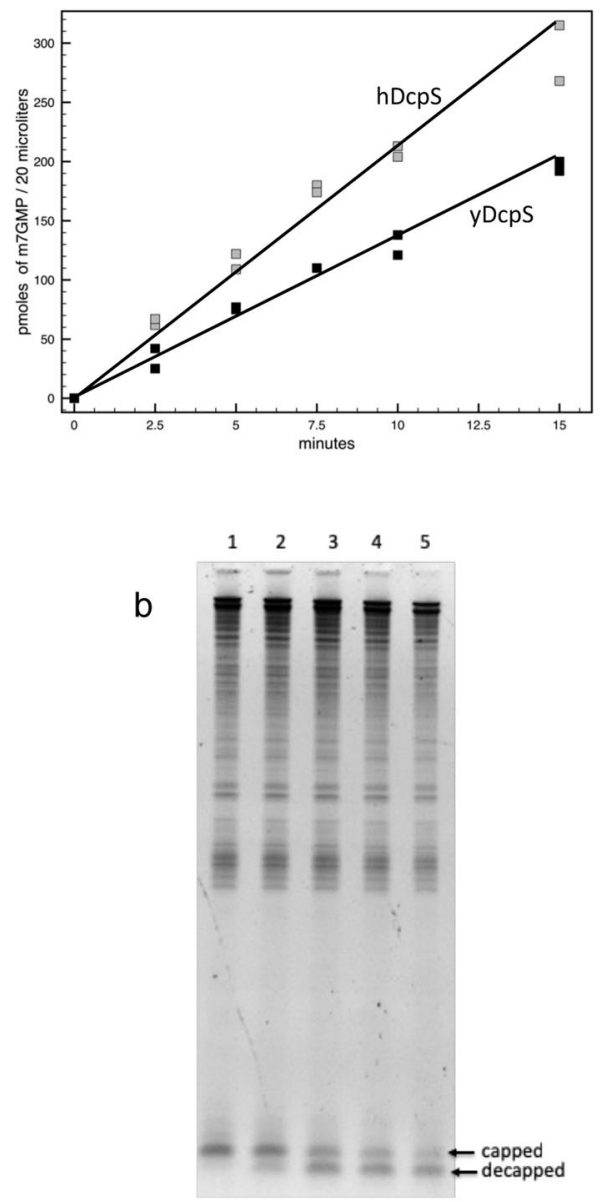

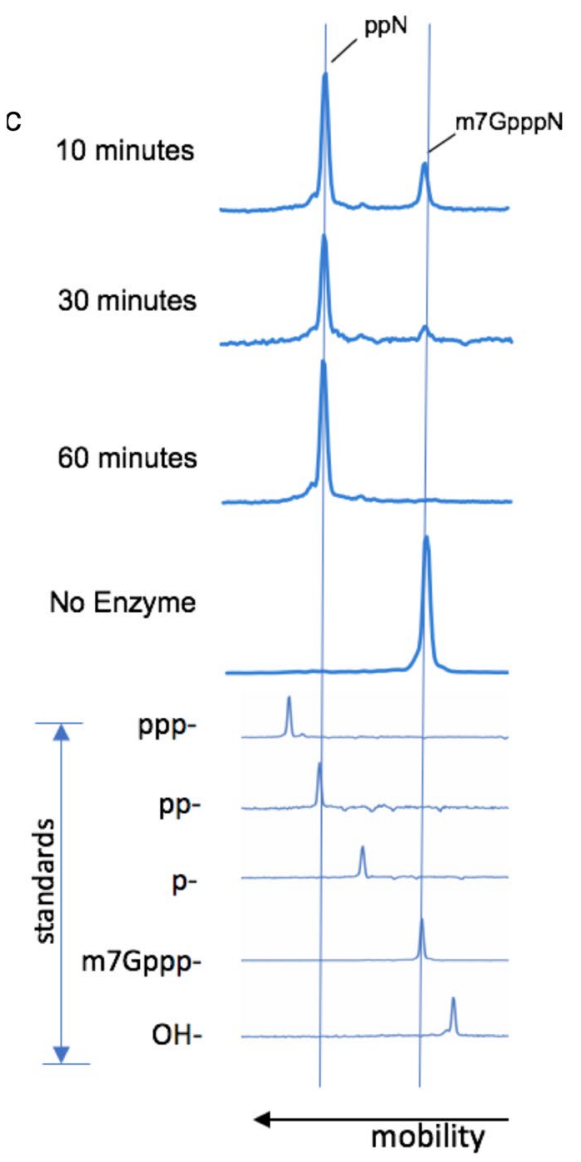

Figure 2. Biochemical Assays for DcpS. (a) Conversion of $\mathrm{m}^{7} \mathrm{GpppA}$ dinucleotide to $\mathrm{m}^{7} \mathrm{GMP}$. A $200 \mu \mathrm{L}$ reaction in decapping buffer containing $50 \mu \mathrm{M} \mathrm{m}^{7} \mathrm{GpppA}$ and either $25 \mathrm{nM}$ yDcpS (black $\square$ ) or $42 \mathrm{nM} \mathrm{hDcpS}$ (grey $\square$ ) was incubated at $37^{\circ} \mathrm{C} .20 \mu \mathrm{L}$ samples were withdrawn at the indicated times. The reactions were terminated by incubation at $70^{\circ} \mathrm{C}$. Picomoles of $\mathrm{m}^{7} \mathrm{GMP}$ product were determined by LC-MS. (b) Decapping of a 25 mer Cap 1 RNA by yDcpS. A $30 \mu \mathrm{L}$ reaction containing $300 \mathrm{ng}$ of total $E$. coli RNA and $60 \mathrm{ng}$ of $25 \mathrm{mer}$ Cap 1 RNA was incubated for 3 hours at $37^{\circ} \mathrm{C}$ with $130 \mathrm{ng}$ of yDcpS in $10 \mathrm{mM} \mathrm{MES} \mathrm{pH} 6.5$ and $1 \mathrm{mM}$ EDTA. At 0 minutes a $5 \mu \mathrm{L}$ aliquot was mixed with $2 \mathrm{X}$ RNA loading dye stop solution (Lane 1). Likewise $5 \mu \mathrm{L}$ aliquots were taken at 5,60,120, and $180 \mathrm{~min}$ (Lanes 2 to 5, respectively). The RNA aliquots were analyzed by $15 \%$ TBE-Urea PAGE stained with SYBR Gold. (c) Capillary electrophoresis of 3'-FAM-labeled 5'-capped 25mer RNA. Top panel shows a representative example of the decapping reaction progress. The 25 mer Cap 0 RNA was incubated with yDcpS for various times indicated on the left. Bottom panel shows the mobility shift for standards of $25 \mathrm{mer}$ RNAs containing different $5^{\prime}$ ends. All data were plotted relative to GeneScan ${ }^{\mathrm{TM}} 120 \mathrm{LIZ}^{\mathrm{TM}}$ Applied Biosystems standards.

8.0 and in phosphate buffer at $\mathrm{pH}$ 7.0. Furthermore in a control reaction with a $5^{\prime}$ triphosphate $3^{\prime}$-FAM labeled $25 \mathrm{mer}$ showed no measurable conversion of the triphosphate to di- or mono-phosphate after incubation with $50 \mu \mathrm{M}$ yDcpS in decapping buffer at $37^{\circ} \mathrm{C}$ for one hour as determined by $\mathrm{CE}$ analysis.

The effect of RNA $5^{\prime}$ secondary structure on decapping accessibility. To determine whether the substrate secondary structure has an impact on the yDcpS activity, complementary synthetic RNA oligos were annealed to the $3^{\prime}$-FAM-labeled 25mer Cap 0 RNA to create a blunt end, a 10 -nucleotide $5^{\prime}$ recessed cap, or a 5 -nucleotide $5^{\prime}$ extended cap end. The extent of decapping was compared to the single-stranded capped $25 \mathrm{mer}$. All 3 double-stranded substrates were decapped, with the $5^{\prime}$ extended cap substrate being decapped as efficiently as the single-stranded control, while the $5^{\prime}$ recessed and blunt ended caps were more resistant to decapping. These results indicate that while yDcpS prefers unstructured $5^{\prime}$ ends, structured ends can also be decapped at higher enzyme concentration (Fig. 3). 


\begin{tabular}{|l|l|l|l|}
\hline Supplemented Salt & \% decapped & Buffer, $\mathbf{p H}$ & \% decapped \\
\hline $0 \mathrm{mM} \mathrm{NaCl}$ & $>95$ & NaOAc $\mathrm{pH} 5.5$ & 33 \\
\hline $5 \mathrm{mM} \mathrm{NaCl}$ & $>95$ & NaOAc pH 6 & 79 \\
\hline $50 \mathrm{mM} \mathrm{NaCl}$ & $>95$ & Bis-Tris $\mathrm{pH} 6.5$ & 82 \\
\hline $100 \mathrm{mM} \mathrm{NaCl}$ & 42 & K phosphate $\mathrm{pH} 7$ & 16 \\
\hline $200 \mathrm{mM} \mathrm{NaCl}$ & 6 & Tris-HCl $\mathrm{pH} 7.5$ & 35 \\
\hline $5 \mathrm{mM} \mathrm{KCl}$ & $>95$ & Tris-HCl pH 8 & 13 \\
\hline $50 \mathrm{mM} \mathrm{KCl}$ & 72 & Tris-HCl $\mathrm{pH} 8.5$ & $<5$ \\
\hline $100 \mathrm{mM} \mathrm{KCl}$ & 20 & VCE Buffer pH 8 & $<5$ \\
\hline $200 \mathrm{mM} \mathrm{KCl}$ & $<5$ & & \\
\hline
\end{tabular}

Table 1. Summary of the effects of reaction conditions on the yDcpS activity. In vitro decapping of $5^{\prime}$-capped synthetic 3'-FAM-labeled RNA under different reaction conditions at $60 \mathrm{nM}$ yDcpS. All reactions contained an additional $30 \mathrm{mM} \mathrm{NaCl}$ because of the contribution from the enzyme storage buffer. The left column shows the effect of salt on the reaction. The yDcpS reaction buffer, which is $10 \mathrm{mM}$ Bis-Tris $\mathrm{pH} 6.5$ and $1 \mathrm{mM}$ EDTA, was supplemented with the indicated concentration of salt. The right column shows the effect of $\mathrm{pH}$ on the reaction. The concentration of each buffering agent was $10 \mathrm{mM}$ and contained $1 \mathrm{mM}$ EDTA. The VCE Buffer is from NEB. See Methods section for more details.

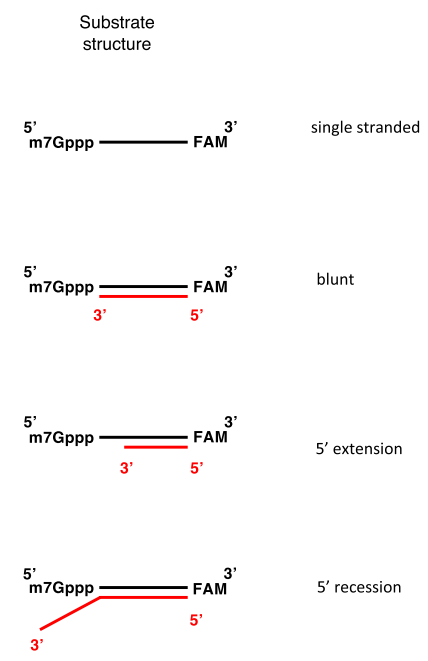

Figure 3. The effect of the secondary structure at the $5^{\prime}$ end of RNA on the decapping activity of yDcpS. Complementary synthetic RNA oligos were annealed to the $3^{\prime}$-FAM-labeled 25mer Cap 0 RNA to create a blunt $(\bigcirc)$, a $5^{\prime}$ extension $(\triangle)$, or a $5^{\prime}$ recession $(\square)$ as depicted on the right. The extent of decapping of each after 60 minutes at $37^{\circ} \mathrm{C}$ with various concentrations of yDcpS was determined by capillary electrophoresis. The following complementary sequences were used for blunt, UUGAGCGUACUCGACGAAGUUCUAC; $5^{\prime}$ extension UUGAGCGUACUCGACGAAGU; and 5' recession, UUGAGCGUACUCGACGAAGUUCUACAAUGACCAUC. The data points are an average of three replicates.

Cap specificity of yDcpS. Liu et al. . $^{4}$ suggested that the cap analog GpppG was not likely a substrate for DcpS because the GpppG dinucleotide at $10 \mu \mathrm{M}$ was not an effective inhibitor of $\mathrm{m}^{7} \mathrm{GpppG}$ decapping. Wypijewska et al. ${ }^{20}$ and Cohen et al. ${ }^{13}$ demonstrated that DcpS from H. sapiens, C. elegans, and A. suum differ from one another as they decap various cap dinucleotide analogs at dissimilar rates. Yeast mRNA caps are only methylated at the $N-7$ position and not at the $2^{\prime}-O$ position ${ }^{21,22}$. In contrast, the majority of the capped structures from HeLa cells are Cap $1\left(\mathrm{~m}^{7} \mathrm{GpppNm}\right)$ and Cap $2\left(\mathrm{~m}^{7} \mathrm{GpppNmNm}\right)$, whereas Cap $0(\mathrm{GpppN})$ has not been identified ${ }^{23,24}$. Additionally, a number of still uncharacterized cap structures have been reported to occur on short RNAs ${ }^{25}$. Hence, we sought to determine the susceptibility of 30 distinct 25mer RNAs featuring different cap structure permutations to decapping with yDcpS (Fig. 4a).

Various capped $25 \mathrm{mer}$ RNA substrates $(100 \mathrm{nM})$ were incubated for 60 minutes at $37^{\circ} \mathrm{C}$ with increasing concentrations of $y D c p S$ varying by a factor of three. The reactions were then analyzed by PAGE and the relative extent of decapping determined after staining and imaging the gels. A typical set of gel images was compiled in Fig. 4b. It can be estimated from the gel electrophoresis results that, $\mathrm{m}^{7} \mathrm{GpppA}, \mathrm{m}^{7} \mathrm{Gpppm}^{6} \mathrm{~A}, \mathrm{~m}^{7} \mathrm{Gpppm}^{6} \mathrm{Am}$, $\mathrm{m}^{7} \mathrm{GpppG}$, and $\mathrm{m}^{7} \mathrm{GpppGm}$ caps were removed at a similar yDcpS concentration of $0.9 \mu \mathrm{M}$, while GpppG required about a 3 -fold higher concentration. Interestingly, while yDcpS can decap deoxyriboguanosine and arabinoguanosine caps, no activity was detected towards 2,2,7-trimethylguanosine, adenosine, cytidine, or uridine 
a

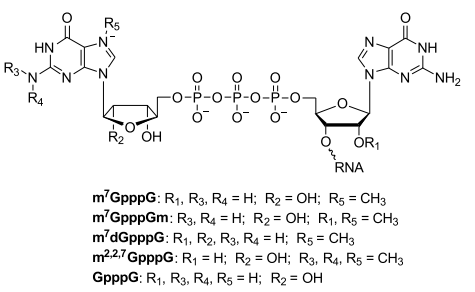

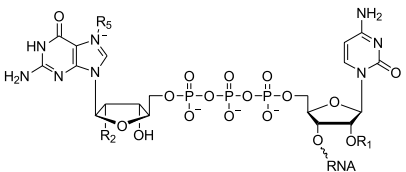

$m^{7} \mathbf{G p p p C}: \mathrm{R}_{1}=\mathrm{H}_{;} \quad \mathrm{R}_{2}=\mathrm{OH} ; \mathrm{R}_{5}=\mathrm{CH}_{3}$ $m^{7} \mathrm{GpppCm:} \mathrm{R}_{2}=\mathrm{OH} ; \mathrm{R}_{1}, \mathrm{R}_{5}=\mathrm{CH}_{3}$ $m^{7} \mathrm{dGpppC}: R_{1}, R_{2}=H ; R_{5}=\mathrm{CH}_{3}$

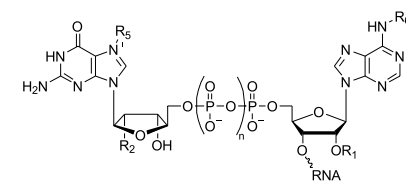

$m^{7} \mathbf{G p p p A}: \mathrm{R}_{1}, \mathrm{R}_{6}=\mathrm{H} ; \mathrm{R}_{2}=\mathrm{OH} ; \mathrm{R}_{5}=\mathrm{CH}_{3} ; \mathrm{n}=2$ GppAm: $R_{6}=H ; R_{2}=O H ; R_{1}, R_{5}=C_{3} ; n=2$

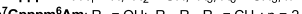
$m^{7}$ dGpppA: $R_{1}, R_{2} R_{6}=H_{1}: R_{5}=R_{6}=n=2$ GppppA: $R_{1}, R_{5}, R_{5}=H: R_{2}=\mathrm{OH}: n=3$ GpppA: $R_{1}, R_{5}, R_{6}=H ; R_{2}=\mathrm{OH}: n=2$ GppA: $R_{1}, R_{5} R_{6}=H ; R_{2}=O H ; n=1$

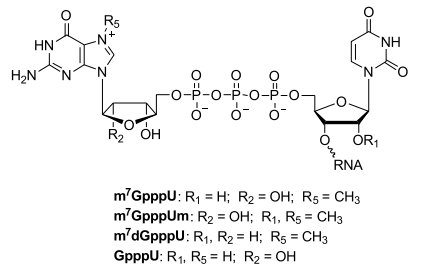
$m^{7} d G p p p U: R_{1}, R_{2}=H ; R_{5}=C_{3}$

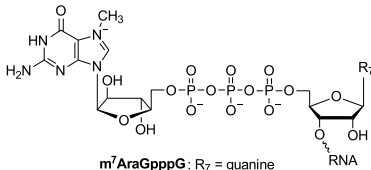

$\mathrm{m}^{7} \mathrm{AraGpppG}: \mathrm{R}_{7}=$ guanine $m^{7}$ AraGpppA: $R_{7}=$ adenine $m^{7} A r a G p p l: R_{7}=$ uracil

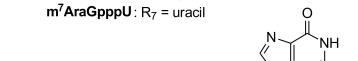

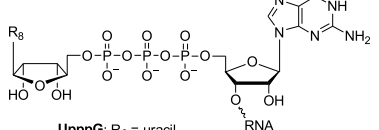

UpppG: $R_{8}=$ uracil CpppG: $R_{8}=$ cytosine IpppG: $R_{8}=$ hypoxanthin

夏<smiles>c1ccccc1</smiles><smiles>Nc1ncnc2c1ncn2C1OC(OP(=O)(O)O)C(OP(=O)(O)O)C1O</smiles>

b

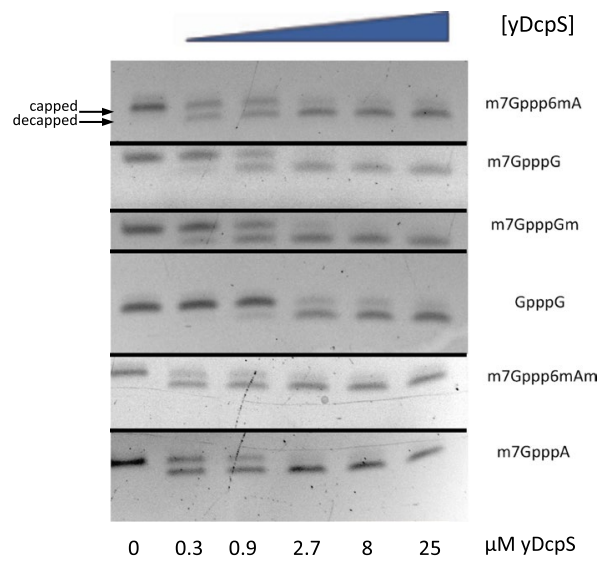

C

\begin{tabular}{|c|c|c|c|c|c|c|c|c|}
\hline$m^{7} G p p p N$ & $\mathrm{~m}^{7} \mathrm{GpppNm}$ & $\mathrm{m}^{7} \mathrm{dGpppN}$ & GpppN & $m^{7}$ AraGpppN & non-GpppG & $\mathrm{m}^{2,2,7} \mathrm{GppN}$ & GppppN & $\mathrm{NppN}$ \\
\hline$m^{7} G p p p G$ & $m^{7} G p p p G m$ & $m^{7} d G p p p G$ & GpppG & $\mathrm{m}^{7} \mathrm{AraGpppG}$ & UpppG & $\mathrm{m}^{2,2,7} \mathrm{GpppG}$ & & \\
\hline $\mathrm{m}^{7} \mathrm{GpppA}$ & $m^{7} G p p p A m$ & $\mathrm{~m}^{7} \mathrm{dGpppA}$ & GpppA & $\mathrm{m}^{7} \mathrm{AraGpppA}$ & CpppG & & GppppA & GppA \\
\hline $\mathrm{m}^{7} \mathrm{Gpppm} \mathbf{6}^{6} \mathrm{~A}$ & $m^{7} \mathrm{Gpppm}^{6} \mathrm{Am}$ & & & & ApppG & & & NAD \\
\hline$m^{7} G p p p C$ & $\mathrm{~m}^{7} \mathrm{GpppCm}$ & $\mathrm{m}^{7} \mathrm{dGpppC}$ & GpppC & $\mathrm{m}^{7} \mathrm{AraGppc}$ & IpppG & & & \\
\hline$m^{7} G p p p U$ & $m^{7} G p p p U m$ & $\mathrm{~m}^{7} \mathrm{dGppU}$ & GpppU & $m^{7} A r a G p p U$ & & & & \\
\hline
\end{tabular}

Figure 4. Relative decapping efficiency of yDcpS with 30 different cap structures on 25 mer RNAs. (a) chemical representation of cap structures. (b) Composite of gel images of 6 decapping reactions of $25 \mathrm{mer}$ RNA substrates $\left(\mathrm{m}^{7} \mathrm{Gppp}{ }^{6} \mathrm{~mA}, \mathrm{~m}^{7} \mathrm{GpppG}, \mathrm{m}^{7} \mathrm{GpppGm}, \mathrm{GpppG}, \mathrm{m}^{7} \mathrm{Gppp}^{6} \mathrm{mAm}, \mathrm{m}^{7} \mathrm{GpppA}\right)$ incubated with increasing concentrations of yDcpS for 60 minutes at $37^{\circ} \mathrm{C}$. The reactions were electrophoresed on a $15 \% \mathrm{TBE}-$ Urea gel and stained with SYBR Gold. The full-length gel images are shown in the Supplemental Information. (c) Substrates decapped (greater than $95 \%$ at $2.7 \mu \mathrm{M}$ yDcpS) are shaded in green and substrates resistant to decapping (less than $10 \%$ at $25 \mu \mathrm{M} \mathrm{yDcpS}$ ) are shaded in pink. Bolded characters indicate canonical cap structures (known or anticipated).

capped RNAs (Fig. 4c). As for the length of the internucleotidic phosphate bridge, yDcpS was able to decap tri- or tetraphosphate, but no diphosphate caps. Not surprisingly, yDcpS had no activity on a nicotinamide adenine dinucleotide (NAD) capped RNA. 


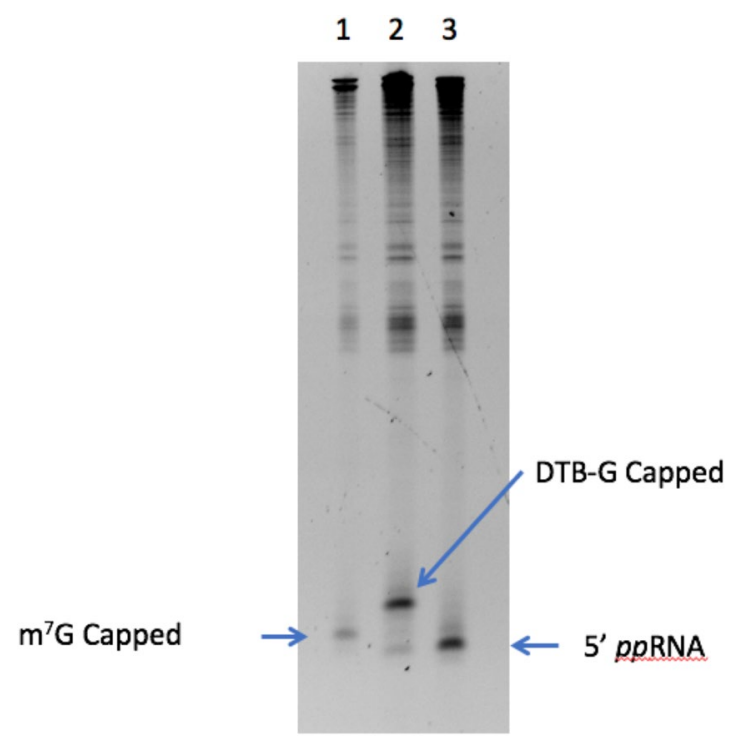

Figure 5. yDcpS decapping of a 25mer Cap1 RNA followed by VCE recapping. A m7 ${ }^{7}$-capped $25 \mathrm{mer}$ RNA $(0.22 \mu \mathrm{g})$ was mixed with $1 \mu \mathrm{g}$ of total $E$. coli RNA and incubated with $0.1 \mathrm{nmol}$ of yDcpS for $2 \mathrm{~h}$ at $37^{\circ} \mathrm{C}$. An aliquot was removed prior to the addition of $\mathrm{yDcpS}$ to provide a reference band for $\mathrm{m}^{7} \mathrm{G}$-capped $25 \mathrm{mer}$ (Lane 1 ). The yDcpS reaction was terminated by addition of Proteinase K and purified using Ampure XP beads. After elution, the RNA was incubated in $1 \mathrm{X}$ VCE buffer containing $0.1 \mathrm{mM}$ SAM and $0.5 \mathrm{mM}$ DTB-GTP in the presence (Lane 2) or absence (Lane 3) of VCE for $1 \mathrm{~h}$ at $37^{\circ} \mathrm{C}$. All samples were electrophoresed on a $15 \% \mathrm{TBE}-$ Urea gel and stained with SYBR Gold.

yDcpS decapping followed by VCE recapping. A characteristic of yDcpS catalysis is the removal of the $\mathrm{m}^{7} \mathrm{G}$ from the cap in the form of $\mathrm{m}^{7} \mathrm{GMP}$ leaving a $5^{\prime}$-diphosphate on the $5^{\prime}$ terminus of the RNA ${ }^{4} .5^{\prime}$-diphosphate RNA is a known substrate for in vitro capping using the Vaccinia virus Capping Enzyme (VCE) ${ }^{12,26,27}$. We took advantage of these two reactions to tag a $\mathrm{m}^{7} \mathrm{G}$-capped 25 mer RNA with an affinity group, by first decapping the RNA with yDcpS, and then recapping it by treatment with VCE and DTB-GTP ${ }^{12}$. These reactions were performed in the presence of excess total E. coli RNA in order to simulate a complex mixture of RNA as would be found in total eukaryotic RNA. As shown by gel electrophoresis for a Cap 1 RNA (Fig. 5) and by mass spectroscopy for Cap 0 (Supplementary Figs S1-S3), the decapping/recapping process approached completion, suggesting that this strategy could be extended to capture and enrich native capped RNA transcripts.

yDcpS decaps long capped RNA transcripts. After demonstrating the efficient decapping and recapping of $\mathrm{m}^{7} \mathrm{G}$-capped 25mer RNAs, we tested whether yDcpS could decap long RNA substrates. We generated a mixture of RNA transcripts with lengths of 90 to 1400 nucleotides by in vitro transcription from a plasmid harboring a T7 promoter upstream of the FLuc gene, which had been cleaved with various restriction endonucleases to generate transcription templates of different lengths (see Methods). The produced RNA transcripts were capped with GTP by VCE to yield $\mathrm{m}^{7} \mathrm{G}$-capped RNAs. The mixture of capped transcripts was then decapped by incubation with $y D c p S$. As a control, an aliquot of the $\mathrm{m}^{7} \mathrm{G}$-capped transcripts was incubated in the absence of yDcpS. Both sets of transcripts were subjected to capping with DTB-GTP by VCE. The recapped products were exposed to streptavidin beads, and after washing steps to remove any unbound material, recovered by elution with biotin. As shown in Fig. 6, no RNA was recovered from the fraction that was not treated with yDcpS (Lane 4), while the full-size range of capped transcripts treated with yDcpS were recovered in the biotin-eluted fraction. This result demonstrates that yDcpS decapping followed by VCE recapping and streptavidin-based recovery of transcripts is an efficient process (approximately 50\% yield) and shows minimal length discrimination. This workflow can thus be applied to eukaryotic mRNA Transcription Start Site (TSS) analysis by appending it to the workflow of Cappable-seq. ${ }^{12}$.

\section{Discussion}

In characterizing yDcpS, we have shown that the methylation status of various canonical guanosine caps (GpppN, $\mathrm{m}^{7} \mathrm{GpppN}, \mathrm{m}^{7} \mathrm{GpppNm}, \mathrm{m}^{7} \mathrm{Gpppm}{ }^{6} \mathrm{~A}$, or $\mathrm{m}^{7} \mathrm{Gpppm}{ }^{6} \mathrm{Am}$ ) does not significantly affect their susceptibility to decapping by this enzyme. We also examined non-canonical $\mathrm{m}^{7} \mathrm{G}$ caps where the ribose moiety was substituted with arabinose or deoxyribose. Although these caps have not been shown to exist in nature, they are also decapped by yDcpS.

Under the conditions described, yDcpS decaps the majority of the guanosine-based caps, regardless of the nucleotide at position +1 . The enzyme prefers $\mathrm{m}^{7} \mathrm{G}$ over nonmethylated $\mathrm{G}$ caps, and does not decap adenosine, cytosine, uridine, or inosine caps. yDcpS decaps $5^{\prime}-5^{\prime}$ triphosphate and tetraphosphate linkages, but not diphosphate linkages. Interestingly, Cohen et al. ${ }^{13}$ reported that nematode DcpS decapped a 2,2,7-trimethylated G cap (commonly found in certain small nuclear and nucleolar RNAs), while the human DcpS did not. We found that yDcpS, resembling hDcpS, did not decap 2,2,7-trimethylated guanosine. The in vitro characterization of yDcpS 


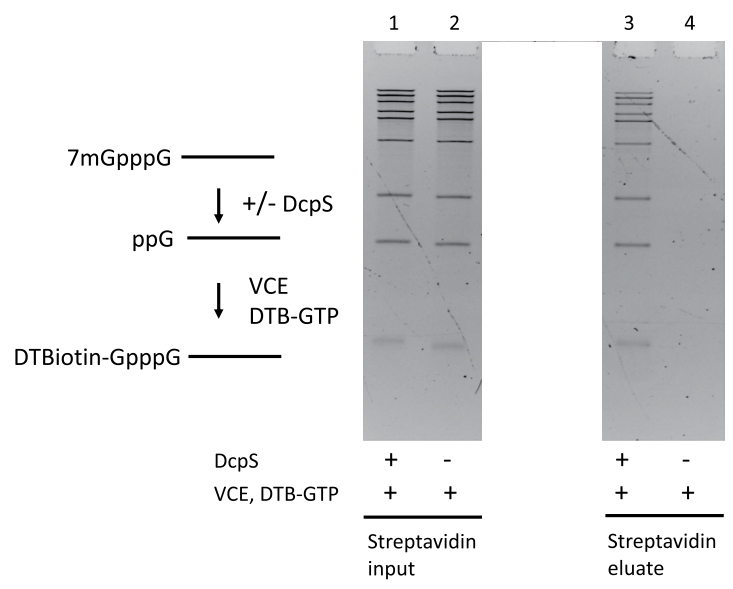

Figure 6. Efficient recovery of long capped RNA transcripts by a decapping/recapping procedure. A mixture of $\mathrm{m}^{7} \mathrm{G}$-capped RNAs $(0.090-1.4 \mathrm{~kb})$ was divided into two samples. One sample was incubated with yDcpS and one without yDcpS, and both were subsequently treated with VCE and DTB-GTP. An equal fraction of each was exposed to streptavidin beads, which were washed and eluted. Lanes $1(+y D c p S)$ and $2(-y D c p S)$ show the samples after the VCE reaction. Lanes $3(+\mathrm{yDcpS})$ and $4(-\mathrm{yDcpS})$ show the eluates from streptavidin beads. All lanes represent an equal fraction of the original mixture. Both gel panels are from the same imaged gel.

presented here provides evidence that yDcpS should be a useful reagent for generating recappable $5^{\prime}$ ends from capped RNAs. We demonstrate that yDcpS decaps $\mathrm{m}^{7} \mathrm{G}$-capped RNAs from as short as 25 to at least 1400 nucleotides, leaving a $5^{\prime}$-diphosphate end. The implications of these in vitro findings suggest that it is possible that the in vivo function of the scavenger decapping enzymes may be more complex.

The process of decapping and recapping with an affinity-tagged nucleotide would be advantageous for identifying and enriching $5^{\prime}$ capped termini of mRNAs in eukaryotes. This would expand the utility of the prokaryotic Cappable-seq method ${ }^{12}$ to include eukaryotic mRNAs. Cappable-seq has been used to determine the transcription start sites of primary transcripts of prokaryotes at single base resolution via the attachment of a biotinylated GTP analogue to the 5'-triphosphate end of primary RNA transcripts by action of the Vaccinia capping enzyme (VCE). The extension of this method to canonical eukaryotic mRNAs requires the removal of the $\mathrm{m}^{7} \mathrm{G}$ moiety to generate a recappable end (such as a tri- or diphosphate $5^{\prime}$ end), which we now show is attainable with the use of yDcpS. Therefore, we anticipate being able to enrich eukaryotic mRNA by combining yDcpS-mediated decapping followed by recapping with affinity tagged GTP and generating libraries for high-throughput sequencing. Progress towards this goal is underway in our laboratory.

\section{Methods}

Preparation of RNAs. The $\mathrm{m}^{7} \mathrm{GpppA}$ dinucleotide cap analog $\mathrm{m}^{7} \mathrm{G}\left(5^{\prime}\right) \mathrm{ppp}\left(5^{\prime}\right) \mathrm{A}$ was obtained from New England Biolabs, Ipswich, MA (NEB). The $5^{\prime}-\left[\mathrm{m}^{7} \mathrm{Gppp}\right.$ ]GUAGAACUUCGUCGAGUACGCUCAA[FAM]-3 was purchased from Bio-Synthesis, Inc. The complementary oligos used for secondary structure experiments for blunt end (UUGAGCGUACUCGACGAAGUUCUAC), 5' cap extension (UUGAGCGUACUCGACGAAGU), and 5' cap recession (UUGAGCGUACUCGACGAAGUUCUACAAUGACCAUC) were purchased from Integrated DNA Technologies (IDT). The 5' -triphosphate 25mer RNAs (5'-ppp-NUAGAACUUCGUCGAGUACGCUCAA- $3^{\prime}$, wherein $\mathrm{N}$ is $\mathrm{G}, \mathrm{C}, \mathrm{A}$, or $\mathrm{U}$ ) utilized for the generation of $\mathrm{m}^{7} \mathrm{GpppN}, \mathrm{m}^{7} \mathrm{GpppNm}, \mathrm{m}^{7} \mathrm{dGpppN}, \mathrm{GpppN}$, and $\mathrm{m}^{7}$ AraGpppN were individually synthesized as previously described ${ }^{28}$. The $5^{\prime}$-monophosphate $25 \mathrm{mer}$ RNAs (5'-p-NUAGAACUUCGUCGAGUACGCUCAA-3', wherein N is $\mathrm{G}, \mathrm{A}$, or $\mathrm{U}$ ) utilized for the generation of $\mathrm{m}^{7} \mathrm{Gpppm}^{6} \mathrm{~A}, \mathrm{~m}^{7} \mathrm{Gpppm}{ }^{6} \mathrm{Am}, \mathrm{GppppA}, \mathrm{GppA}$, and NpppG (wherein $\mathrm{N}$ is $\mathrm{U}, \mathrm{C}, \mathrm{A}$, or I) were synthesized by standard phosphoramidite chemistry on an ABI 394 DNA/RNA synthesizer. For the synthesis of $5^{\prime}-p-m^{6}$ AUAGAACUUCGUCGAGUACGCUCAA-3', a N6-Methyl-A-CE phosphoramidite from Glen Research was utilized. Detailed protocols for the enzymatic or chemical generation of the $5^{\prime}$-capped 25 mer RNAs utilized in this study are described in the Supplementary Information section.

Preparation of yDcpS. The gene for the Saccharomyces cerevisiae yDcpS (YLR270W) was codon optimized for E. coli expression and designed with an amino terminal His tag to be expressed from a T7 promoter in plasmid pET28a (Supplementary Fig. S4). The predicted molecular weight of the fusion is 42,945 daltons. The construct was synthesized by Genscript. The protein was expressed in E. coli ER3600 and purified to near homogeneity (greater than 95\%) by chromatography over HisTrap, SP, and Q resins. The protein's size as determined by SDS-PAGE is consistent with its predicted molecular weight (Supplementary Fig. S5). The final preparation of

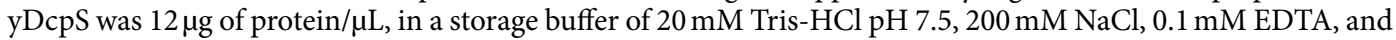
$50 \%$ glycerol. The protein was stored at $-20^{\circ} \mathrm{C}$. The DcpS preparation was determined to be free of detectable RNAse contamination by assay with a 300 mer RNA transcript $(\sim 100 \mathrm{ng})$ incubated with $12 \mu \mathrm{g}$ of yDcpS in a $20 \mu \mathrm{L}$ reaction in the decapping buffer $10 \mathrm{mM}$ Bis-Tris pH 6.5, $1 \mathrm{mM}$ EDTA, and in $20 \mathrm{mM}$ Tris-Acetate pH 7.9 buffer containing $50 \mathrm{mM}$ potassium acetate, $10 \mathrm{mM}$ magnesium acetate, and $1 \mathrm{mM}$ DTT for 4 hours. No degradation of the 300 mer band by PAGE analysis was observed. 
Human DcpS. Human DcpS (hDcpS) was purchased from Enzymax LLC, Lexington, KY. The protein concentration of DcpS was determined by $\mathrm{OD}_{280}$ using the molar extinction coefficient of $30495 \mathrm{M}^{-1} \mathrm{~cm}^{-1}$.

Decapping reactions. Unless otherwise noted, the decapping was carried out at $37^{\circ} \mathrm{C}$ in the decapping buffer $10 \mathrm{mM}$ Bis-Tris pH 6.5, $1 \mathrm{mM}$ EDTA. With the exception of the reactions containing FAM-labeled RNAs (see below), all reactions using capped 25mer RNA substrates were terminated by the addition of 1 volume of 2X RNA loading dye (NEB). The reactions using the $\mathrm{m}^{7} \mathrm{GpppA}$ dinucleotide cap analog were terminated by $70^{\circ} \mathrm{C}$ heat inactivation.

In vitro decapping of $5^{\prime}$-capped synthetic $3^{\prime}$-FAM-labeled RNA. In vitro decapping reactions were carried out in a $20 \mu \mathrm{L}$ reaction containing $10 \mathrm{mM}$ Bis-Tris $\mathrm{pH} 6.5,1 \mathrm{mM}$ EDTA, $500 \mathrm{nM}$ substrate RNA $\left(5^{\prime}-\left[\mathrm{m}^{7} \mathrm{Gppp}\right]\right.$ GUAGAACUUCGUCGAGUACGCUCAA[FAM]-3, Bio-Synthesis, Inc.), and $60 \mathrm{nM}$ yDcpS at $37^{\circ} \mathrm{C}$ for $60 \mathrm{~min}-$ utes, unless otherwise indicated (Table 1). Reactions were stopped by heat inactivation at $70^{\circ} \mathrm{C}$ for 15 minutes. Reactions were diluted in nuclease-free water to reach a final substrate concentration of $5 \mathrm{nM}$ before capillary electrophoresis on either an Applied Biosystems 3130xl Genetic Analyzer (16 capillary array) or an Applied Biosystems 3730xl Genetic Analyzer (96 capillary array) using GeneScan 120 LIZ dye Size Standard (Applied Biosystems). Reaction products were analyzed using PeakScanner software (Thermo Fisher Scientific) and an in-house software suite. The electrophoretic mobility of the Cap 0 substrate and the $5^{\prime}$-diphosphate product was calibrated against RNA standards generated enzymatically from a synthetic $5^{\prime}$-triphosphate $25 \mathrm{mer}$. The $5^{\prime}$-diphosphate standard was generated by treating the chemically synthesized $5^{\prime}$-triphosphate $/ 3^{\prime}$-FAM-labeled 25 mer with the $S$. cerevisiae Cet $1^{29}$. The $5^{\prime}$-monophosphate standard was generated by treating the $5^{\prime}$-triphosphate/3'-FAM-labeled 25 mer with Apyrase (NEB). The $5^{\prime}$-hydroxyl standard was generated by treating the $5^{\prime}$-triphosphate $/ 3^{\prime}$-FAM-labeled 25 mer with calf intestinal phosphatase (NEB). The cap 0 standard was generated by treating the $5^{\prime}$-triphosphate $/ 3^{\prime}$-FAM-labeled 25 mer with Vaccinia virus capping enzyme (VCE, NEB) in the presence of GTP and $S$-adenosylmethionine (SAM). The RNA standards were purified using RNA Clean and Concentrator kit (Zymo Research). The identity of the standards was verified by intact mass spectrometry. The $25 \mathrm{mer}$ Cap 1 RNA was generated by treating the chemically synthesized 3'-FAM-labeled Cap 0 25mer RNA with mRNA Cap 2'-O-Methyltransferase (NEB) in the presence of SAM. The Cap $125 \mathrm{mer}$ RNA was purified using Monarch RNA Cleanup kit (50 $\mu$ g capacity, NEB). Complete methylation was verified by digestion of RNA with the Nucleoside Digestion Mix (NEB, M0649) and LC-MS analysis.

In vitro cap specificity assay of yDcpS with 30 different cap structures. The reaction conditions for decapping consisted of $100 \mathrm{nM} 5^{\prime}$-capped $25 \mathrm{mer}$ RNA and $0,0.3,0.9,2.7,8$ or $25 \mu \mathrm{M} \mathrm{DcpS}$ in a $10 \mu \mathrm{L}$ reaction volume in $10 \mathrm{mM}$ Bis-Tris pH 6.5 and $1 \mathrm{mM}$ EDTA. The reactions were incubated for 60 minutes at $37^{\circ} \mathrm{C}$ and terminated by the addition $2 \mu \mathrm{L}$ of Proteinase K (NEB) which had been supplemented with 0.1 reaction volume of $1 \mathrm{M}$ Tris- $\mathrm{HCl} \mathrm{pH} \mathrm{8.0,} \mathrm{and} \mathrm{further} \mathrm{incubated} \mathrm{for} 5$ minutes at room temperature. To each $12 \mu \mathrm{L}$ reaction was added $12 \mu \mathrm{L}$ of RNA loading dye (2X) (NEB). This mixture was heat denatured at $80^{\circ} \mathrm{C}$ for 3 minutes, and an aliquot of $5 \mu \mathrm{L}$ was loaded onto a $15 \%$ polyacrylamide TBE-Urea gel (Invitrogen). The gel was run at 180 volts for 75 minutes. The RNA was visualized with SYBR Gold stain.

Decapping 25mer with yDcpS and recapping with $3^{\prime}$-Desthiobiotin-GTP. A $100 \mu \mathrm{L}$ reaction in $10 \mathrm{mM}$ MES pH 6.5 and $1 \mathrm{mM}$ EDTA containing $0.22 \mu \mathrm{g}$ of $25 \mathrm{mer}$ Cap1 RNA and $0.1 \mathrm{nmol}$ of yDcpS, and $1 \mu \mathrm{g}$ of total $E$. coli RNA, was incubated for 2 hours at $37^{\circ} \mathrm{C}$. Before addition of the yDcpS, a $2 \mu \mathrm{L}$ sample of the reaction was removed. The yDcpS reaction was terminated by addition of $4 \mu \mathrm{L}$ of $1 \mathrm{M}$ Tris $\mathrm{HCl} \mathrm{pH} 8.0$ and $2 \mu \mathrm{L}$ of Proteinase K. The reaction was further incubated for 30 minutes at $37^{\circ} \mathrm{C}$ and then heated to $94^{\circ} \mathrm{C}$ for 3 minutes. The RNA was purified by binding to Ampure XP beads (Beckman Coulter) by addition of 2 volumes of beads, and to that final volume additional 1.5 volumes of ethanol. After washing the beads with $80 \%$ ethanol, the RNA was eluted in $30 \mu \mathrm{L}$ of $1 \mathrm{mM}$ Tris $\mathrm{pH} 7.5$ and $0.1 \mathrm{mM}$ EDTA. A $20 \mu \mathrm{L}$ reaction containing $1 \mathrm{X}$ VCE buffer (NEB), $10 \mu \mathrm{L}$ of the eluted RNA, $0.1 \mathrm{mM}$ SAM, $0.5 \mathrm{mM}$ DTB-GTP (NEB) was split into two $9.5 \mu \mathrm{L}$ reactions: in one tube was added $1 \mu \mathrm{L}$ of VCE and in the other tube was added $1 \mu \mathrm{L}$ of water. The reactions were incubated at $37^{\circ} \mathrm{C}$ for 30 minutes. Samples were electrophoresed on a 15\% TBE-Urea gel (Invitrogen) and stained with SYBR Gold (Fig. 5). A similar experiment for decapping and recapping was carried out with a Cap $025 \mathrm{mer}$ RNA. The results of this experiment were confirmed by mass spectrometry (Supplementary Figs S1-S3).

Preparation of long (0.09-1.4 kb) $\mathrm{m}^{7} \mathrm{G}$-capped transcripts. $\mathrm{m}^{7} \mathrm{G}$-capped RNA substrates 90 to 1400 nucleotides long were generated by T7 RNA polymerase (NEB) transcription of different DNA templates generated from an FLuc plasmid, each digested with one of the following restriction endonucleases: NlaIV, HpyCH4V, Hpy166II, PsiI, AflIII, EcorI, BspQI, BcoDI, or EcoRV in separate reactions. The resulting RNA transcripts comprised 90, 171, 240, 419, $587,681,896,1117$, and 1432 nucleotides, respectively. The individual transcripts were combined in approximate equal amounts. The transcript mixture was subsequently capped by standard VCE capping reaction with GTP and SAM.

Data acquisition and settings. RNA was loaded onto 6\% or 15\% PAGE Urea gels and electrophoresed for 75-85 minutes at $180 \mathrm{~V}$. The gels were stained with SYBR Gold and imaged with an AlphaImager HP. The images were imported into Photoshop, inverted and levels were auto-adjusted.

\section{References}

1. Song, M. G., Bail, S. \& Kiledjian, M. Multiple Nudix family proteins possess mRNA decapping activity. RNA 19, 390-399 (2013).

2. Brenner, C. Hint, Fhit and GalT: function, structure, evolution, and mechanism of three branches of the histidine triad superfamily of nucleotide hydrolases and transferases. Biochemistry 41, 9003-9014 (2002).

3. Martin, J. J., St-Pierre, M. V. M. \& Dufour, J.-F. J. Hit proteins, mitochondria and cancer. Biochim. Biophys. Acta BBA - Bioenerg 1807, 626-632 (2011) 
4. Liu, H., Rodgers, X., Jiao, X. \& Kiledjian, M. The scavenger mRNA decapping enzyme DcpS is a member of the HIT family of pyrophosphatases. EMBO J 21, 4699-4708 (2002).

5. Wang, Z. \& Kiledjian, M. Functional Link between the Mammalian Exosome and mRNA Decapping. Cell 107, 751-762 (2001).

6. Chen, N., Walsh, M. A., Liu, Y., Parker, R. \& Song, H. Crystal Structures of Human DcpS in Ligand-free and m7GDP-bound forms Suggest a Dynamic Mechanism for Scavenger mRNA Decapping. J. Mol. Biol. 347, 707-718 (2005).

7. Kramer, S. \& McLennan, A. G. The complex enzymology of mRNA decapping: Enzymes of four classes cleave pyrophosphate bonds. Wiley Interdiscip. Rev. RNA 10, e1511 (2019).

8. Taverniti, V. \& Seraphin, B. Elimination of cap structures generated by mRNA decay involves the new scavenger mRNA decapping enzyme Aph1/FHIT together with DcpS. Nucleic Acids Res 43, 482-492 (2015).

9. Kramer, S. The ApaH-like phosphatase TbALPH1 is the major mRNA decapping enzyme of trypanosomes. PLOS Pathog. 13, e1006456 (2017)

10. Liu, S.-W. et al. Functional analysis of mRNA scavenger decapping enzymes. RNA 10, 1412-1422 (2004).

11. Bail, S. \& Kiledjian, M. DcpS, a general modulator of cap-binding protein-dependent processes? RNA Biol. 5, 216-219 (2008).

12. Ettwiller, L., Buswell, J., Yigit, E. \& Schildkraut, I. A novel enrichment strategy reveals unprecedented number of novel transcription start sites at single base resolution in a model prokaryote and the gut microbiome. BMC Genomics 17 (2016).

13. Cohen, L. S. et al. Nematode $\mathrm{m} 7 \mathrm{GpppG}$ and $\mathrm{m} 3(2,2,7) \mathrm{GpppG}$ decapping: Activities in Ascaris embryos and characterization of C. elegans scavenger DcpS. RNA 10, 1609-1624 (2004).

14. Milac, A. L., Bojarska, E. \& Wypijewska del Nogal, A. Decapping Scavenger (DcpS) enzyme: Advances in its structure, activity and roles in the cap-dependent mRNA metabolism. Biochim. Biophys. Acta BBA - Gene Regul. Mech 1839, 452-462 (2014).

15. Salehi, Z. et al. A nuclear protein in Schizosaccharomyces pombe with homology to the human tumour suppressor Fhit has decapping activity. Mol. Microbiol 46, 49-62 (2002).

16. Piecyk, K. et al. Effect of different N7 substitution of dinucleotide cap analogs on the hydrolytic susceptibility towards scavenger decapping enzymes (DcpS). Biochem. Biophys. Res. Commun. 464, 89-93 (2015).

17. van Dijk, E., Le Hir, H. \& Séraphin, B. DcpS can act in the $5^{\prime}-3^{\prime}$ mRNA decay pathway in addition to the $3^{\prime}-5^{\prime}$ pathway. Proc. Natl. Acad. Sci. 100, 12081-12086 (2003).

18. Malys, N. \& McCarthy, J. E. G. Dcs2, a Novel Stress-induced Modulator of m7GpppX Pyrophosphatase Activity that Locates to P Bodies. J. Mol. Biol. 363, 370-382 (2006).

19. Liu, S.-W., Rajagopal, V., Patel, S. S. \& Kiledjian, M. Mechanistic and kinetic analysis of the DcpS scavenger decapping enzyme. J. Biol. Chem. 283, 16427-16436 (2008).

20. Wypijewska, A. A. et al. 7-methylguanosine diphosphate (m(7)GDP) is not hydrolyzed but strongly bound by decapping scavenger (DcpS) enzymes and potently inhibits their activity. Biochemistry 51, 8003-8013 (2012).

21. Mager, W. H., Klootwijk, J. \& Klein, I. Minimal methylation of yeast messenger RNA. Mol. Biol. Rep. 3, 9-17 (1976).

22. Sripati, E., Groner, Y. \& Warner, R. Methylated, Blocked 5' Termini of Yeast mRNA*. JBC 251, 2898-2904 (1976).

23. Furuichi, Y. et al. Methylated, blocked 5 termini in HeLa cell mRNA. Proc. Natl. Acad. Sci. 72, 1904-1908 (1975).

24. Furuichi, Y. Discovery of m7G-cap in eukaryotic mRNAs. Proc. Jpn. Acad. Ser. B 91, 394-409 (2015).

25. Abdelhamid, R. F. et al. Multiplicity of 5' Cap Structures Present on Short RNAs. PLoS ONE 9, e102895 (2014).

26. Martin, S. A., Paoletti, E. \& Moss, B. Purification of mRNA Guanylyltransferase and mRNA(guanine-7-)methyltransferase from Vaccinia Virions. J. Biol. Chem. 250, 9322-9329 (1975).

27. Martin, S. A. \& Moss, B. Modification of RNA by mRNA Guanylyltransferase and mRNA(guanine-7)methyltransferase from Vaccinia Virions. JBC 250, 9330-9335 (1975).

28. Goldeck, M., Tuschl, T., Hartmann, G. \& Ludwig, J. Efficient Solid-Phase Synthesis of pppRNA by Using Product-Specific Labeling. Angew. Chem. Int. Ed. 53, 4694-4698 (2014).

29. Ho, C. K., Schwer, B. \& Shuman, S. Genetic, Physical, and Functional Interactions between the Triphosphatase and Guanylyltransferase Components of the Yeast mRNA Capping Apparatus. Mol. Cell. Biol. (1998).

\section{Acknowledgements}

We thank New England Biolabs for supporting this work.

\section{Author Contributions}

I.S. conceived and designed the study. I.S. and I.R.C.J. wrote the manuscript with input from all the authors. M.W. and J.B. synthesized the majority of variously capped RNAs. E.M., G.T., J.W. and I.S. performed biochemical assays. K.M. and I.S. purified the proteins. S.-H.C. developed the CE assays and N.D. performed LC-MS analysis. All authors approved the manuscript.

\section{Additional Information}

Supplementary information accompanies this paper at https://doi.org/10.1038/s41598-019-45083-5.

Competing Interests: All authors are employees of New England Biolabs. New England Biolabs commercializes reagents for molecular biological applications.

Publisher's note: Springer Nature remains neutral with regard to jurisdictional claims in published maps and institutional affiliations.

Open Access This article is licensed under a Creative Commons Attribution 4.0 International License, which permits use, sharing, adaptation, distribution and reproduction in any medium or format, as long as you give appropriate credit to the original author(s) and the source, provide a link to the Creative Commons license, and indicate if changes were made. The images or other third party material in this article are included in the article's Creative Commons license, unless indicated otherwise in a credit line to the material. If material is not included in the article's Creative Commons license and your intended use is not permitted by statutory regulation or exceeds the permitted use, you will need to obtain permission directly from the copyright holder. To view a copy of this license, visit http://creativecommons.org/licenses/by/4.0/.

(C) The Author(s) 2019 